\title{
How American EMRs came to dominate Canadian health care
}

\author{
- Cite as: CMAJ 2019 July 2;191:E749-50. doi: 10.1503/cmaj.109-5765
}

Posted on cmajnews.com on June 13, 2019.

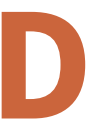

octors and hospital administrators in Nova Scotia are still scratching their heads over how the province's tender for a multibilliondollar electronic medical record (EMR) system descended into corporate intrigue. Underdog firms Cerner Corporation and Allscripts Healthcare Solutions Inc. emerged as finalists; major vendors Meditech Information Technology Inc. and Epic Systems Corporation found themselves out of the running, the latter disqualified for missing the competition's deadline.

Regardless of how the drama plays out, all of the players are large American firms that dominate markets around the world. In the United States, Epic handles some two-thirds of all electronic patient files. The company's share in Canada is about half that proportion, but together with Meditech and Cerner their products control more than $90 \%$ of EMRs in this country. This concentration of major vested interests suggests there is more to EMR purchasing decisions than providing doctors with high-tech replacements for paper records.

"Who's buying the technology?" asks Dr. Karim Keshavjee of the University of Toronto's faculty of health policy, management and evaluation, who has spent more than 20 years studying EMRs. "It's the administrators, because they have to report on their financials. The government does not care how well you looked after this person or that person. They care about whether you spent your money wisely and whether you should have the same budget next year. That becomes the raison d'être for what system you're going to purchase."

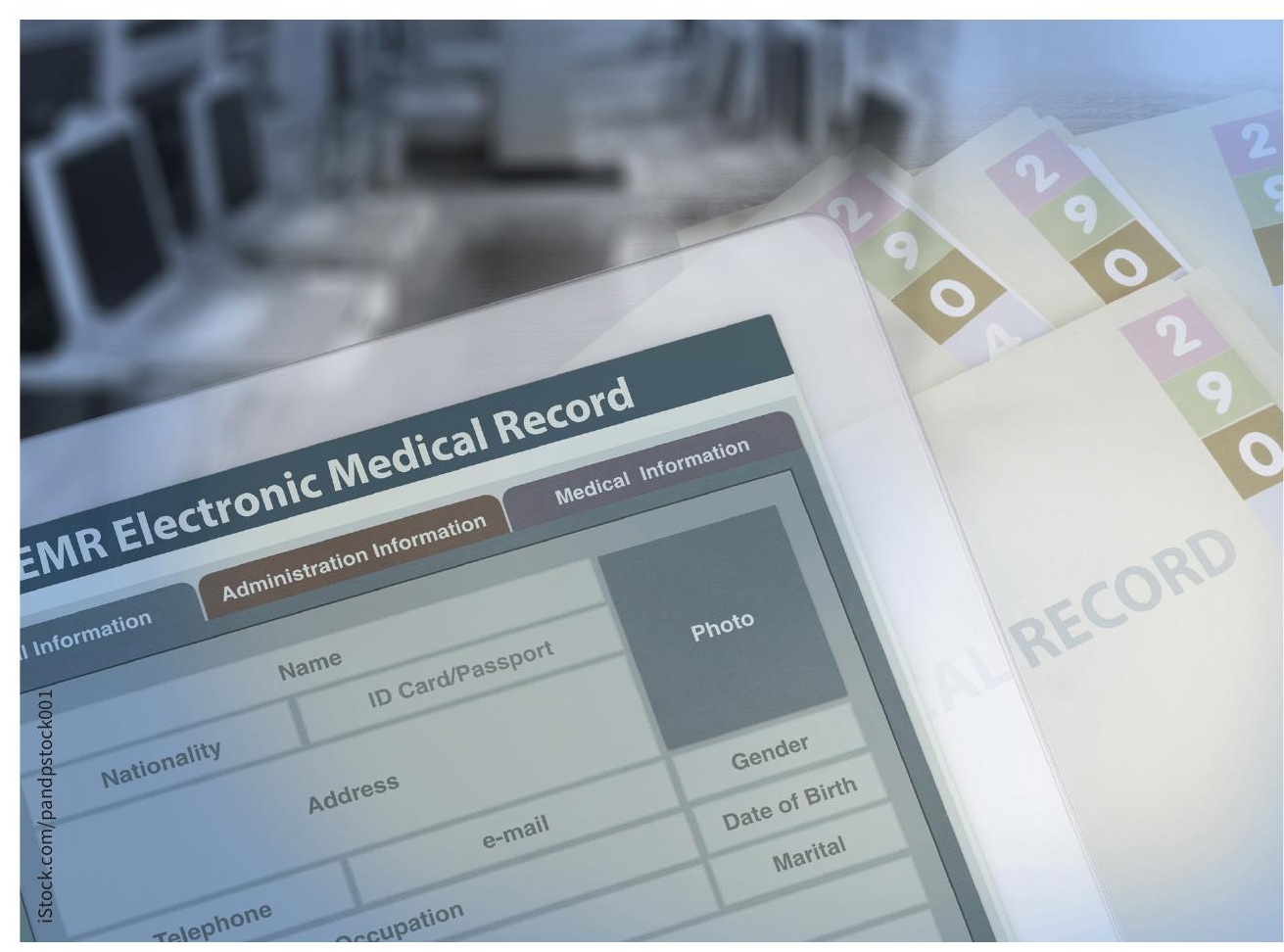

A handful of American EMR vendors control 90\% of the Canadian market.

Some of the earliest commercial EMRs, in the 1990s, focused on the financial side of health care; many clinical details had to be developed separately. According to Keshavjee, this approach was expensive and difficult to maintain, requiring more technical expertise than most users or institutions could muster. Next came large, complex, stand-alone systems to meet the many needs of big hospitals, from exchanging radiological images to tracking the pharmacy's inventory. These systems also came with sophisticated versions of every digital product's best friend: technical support.

"When you've been in business for a long time in EMR, you are the front line of support for every single thing that happens," said Julia Zarb, who directs the master of health informatics program at the University of Toronto. She also lived through the corporate history of these products, with 11 years on vendor executive teams and seven years as a consultant.

"You're bringing more technology roles into non-technology spaces and that creates opportunity for a lot of discord," she said, pointing to the virtues of wellsupported EMRs that relieve hospitals of the need to become their own information technology shops. "I always get very wary when health care organizations take on the role of becoming tech companies. Companies who have had their noses 
bloodied in so many ways should be the ones to deal with this, because there's just too much at stake."

Zarb says that same virtue can account for key decisions in the past few years that have seen Epic's star rise over the Canadian landscape, with a \$459-million deal with Alberta Health Services, as well as becoming the EMR provider for Toronto's Hospital for Sick Children, Ottawa's Children's Hospital of Eastern Ontario, the Ottawa Hospital system, and other sites across the country. It also accounts for why Canada's EMR companies were not poised to compete at this level.
"What home-grown vendors often don't have is the depth of learning," she said, suggesting that Canadian vendors lack the financial resources to carry out ongoing research and development for their products on the same scale. Epic has placed a premium on this strategy, which enables customers to acquire a system that may not be perfect for their needs today, but which the company will help them tailor and refine to suit those needs.

Dr. Karim Jessa, the chief medical information officer at SickKids, has been overseeing the adoption of Epic's EMR. He brought input from the hospital's entire user population to bear on the process, from pre-purchase selection to postinstallation troubleshooting.

"We've been live for more than a year and we have clinicians advising us on tweaks and changes," he said, adding that the specific features of the product are less important that its ability to evolve as necessary to become an integral part of the workplace. "Whether you get a red widget or a blue widget, it's how you're going to use that widget. How are you going to incorporate that into your dayto-day activities?"

Tim Lougheed, Bath, Ont. 